\title{
István TARRÓSY
}

University of Pécs, Hungary

tarrosy.istvan@pte.hu

\section{Zoltán VÖRÖS}

University of Pecs, Hungary

voros.zoltan@pte.hu

\section{EDUCATION AND DEVELOPMENT \\ IN THE SINO-AFRICAN CONTEXT \\ OF RELATIONS}

\section{THE CASES OF TANZANIA AND SUDAN}

ABSTRACT This study focuses on the involvement of China in the above two African states, arguing that the development of the education sector, therefore the development via education is crucial for any of the states of the continent. It gives an overview of education as a significant aspect of human development in the context of opposing policies of the international financial institutions (IFIs) and the Chinese government. In the light of the FOCAC process, China's involvement in the development of human resources on African soil will be looked at closely, also questioning whether or not China may present an 'alternative' to the IFIs in the field.

Keywords: development via education, China in Africa, international financial institutions, Tanzania, Sudan 


\section{INTRODUCTION}

One of the points of reference for this investigation is the concept of state failure ${ }^{1}$ elaborated upon by Rotberg (2004), who underscores that it is according to the performance of states - according to the levels of their effective delivery of the most crucial political [public] goods - that strong states may be distinguished from weak ones, and weak states from failed or collapsed states. ${ }^{2}$ The number one priority among all goods, as Rotberg also emphasizes, is human security. Among the various definitions of state failure, for our arguments we chose one of the simplest that is closely related with the ability or rather disability of managing conflicts. In addition, states in the process of weakening also show vulnerability in their ability to provide different services for their populations. Basically, weak states simply cannot provide basic services - neither the so-called regal services (i.e. ranging from coinage to war management), nor modern services such as health care or education, or security at large - for the citizens of their territories. There is a definite road to get into the phase of state failure, but the aim of this paper is not to look into that. As Putzel explains: While not all poor countries are characterised by $\gg$ state fragility $\ll$, most fragile states are poor, with populations that live on the margins of survival. ${ }^{3}$ The intention of this paper is to give an overview of possible 'ways out' of the crises of statehood with the help of education and human capacity building. We will look into the external factors and actors of developing sub-Saharan African societies in crises, together with some better examples of the Black Continent.

Education is the cornerstone of human development in every society. [...] For, when all is said and done, development is about people. ${ }^{4}$ Or better to say: this should be the case anywhere in the world. Today, there are even more challenges African societies must face and respond to than during the colonial era. It is easily proven that since gaining independence across the continent numerous developments in the education sector have taken shape and have been achieved. For instance, just in the case of Tanzania, one of the most politically stable countries in Africa, between 1970 and 2010, in four decades only the number of higher education institutions - including public and private -

1 One of the most extensive bibliographies on the topic can be found in Robert I. Rotberg's books, see more here: R.I. Rotberg, When States Fail. Causes and Consequences, Princeton 2004, and idem, State Failure and State Weakness in a Time of Terror, Cambridge, Mass. 2003. How states fail has been indexed by the Fund for Peace since 2005. The Fragile State Index (FSI) uses 12 indicators to measure and rank countries on an annual basis. See more: <http://fsi.fundforpeace.org $>$.

2 R.I. Rotberg, When States Fail..., p. 2.

3 J. Putzel, Regional and Global Drivers of Conflict: Consequences for Fragile States and Regions. Paper presented at the World Bank Headline Seminar on the Regional and Global Dimensions of Conflict and Peace Building. Addis Ababa, October $10 \& 12$ October 2009, at <http://www.lse.ac.uk/internationalDevelopment/research/crisisStates/download/others/RGDriversOfChangeOct09JP.pdf>, 20 January 2016.

4 F. Cheru, African Renaissance. Roadmaps to the Challenge of Globalization, London 2002, p. 64. 
has grown to well over twenty. ${ }^{5}$ In 2012, according to the Southern African Regional University Association (SARUA) report, there were 41 higher education institutions, of which 8 were publicly-funded universities, 11 were publicly-funded technical universities or colleges, and 22 were privately-funded, accredited universities or colleges. ${ }^{6}$ Many scholars and analysts say there is no problem for the time being with the numbers; the real issue is 'quality education'. Again, as Cheru argues: Education systems are not keeping pace with changes in the economy and technology that have enormous impacts on the type of skills and the critical thinking required in the emerging world economy. Today's low-quality education has serious implications for tomorrow's development tasks.? A substantial number of these societies still, first of all, struggle with state weakening and shortcomings, then, they are exposed to pushes coming from the global environment. However, in real macroeconomic figures (such as the GDP) Africa at large and African states in their own forms perform very well, much better during the last global financial crisis than their "counterparts" in the technologically more developed world, and the dynamism their economies show in the last years is sometimes remarkable; integration into the world economic structures and processes reserves further hardships. Many of them still feel the failure of the forced reforms in the form of the Structural Adjustment Policies (SAPs) of the international monetary institutions, such as the International Monetary Fund (IMF) and the World Bank (WB). These economic reform programmes hit the education and health sectors the hardest. The most important task should have been and still is for countries of sub-Saharan Africa to proceed very cautiously down the path, as Joseph Stiglitz underlined in an interview in April 2000. He also pointed out that, for developing countries, capital market liberalisation is not associated with faster economic growth and is associated with greater volatility. ${ }^{8}$ If this is not taken into account in a proper way, also looking deep into the very local needs and circumstances, everything can go even worse. Partially as a result of sectoral cuts, coupled with the liberalisation of education (as a market) and other accompanying crises, by the early years of the new millennium, sub-Saharan Africa [became] the only region in the developing world where total educational expenditure have been declining over the past two decades. ${ }^{9}$ As Asad Ismi noted in his paper in which he analysed the World Bank and the IMF in Africa, 10 governments spent more on paying back international debts to these institutions than on primary education and health care combined. Forty percent of African children are out of school and Africa is the only region where this number

5 The University of Dar es Salaam was established in 1970 after the split of the University of East Africa (1963), which was then shared by the three new nation-states of East Africa, i.e. Tanzania, Kenya and Uganda.

6 'Tanzania Data Profile', SARUA study, 2012, at <http://www.sarua.org/files/Country\%20Reports\%202012/Tanzania\%20data\%20profile\%20Eng.pdf>, 2 February 2016.

F. Cheru, African Renaissance..., p. 65.

8 'Unraveling the Washington Consensus. An interview with Joseph Stiglitz', Multinational Monitor, Vol. 21, No. 4 (2000), at <http://www.multinationalmonitor.org/mm2000/00april/interview. html>, 10 November 2015.

9 F. Cheru, African Renaissance. Roadmaps to the Challenge of Globalization. London 2002. p. 65. 
is rising. ${ }^{10}$ So, despite the original goals, the adjustment programmes eviscerated plenty of the African states, leaving them in poverty with demolished health and education sectors. As U.N. Secretary General Javier Perez de Cuellar noted in 1991: The various plans of structural adjustment - which undermine the middle classes; impoverish wage earners; close doors that had begun to open to the basic rights of education, food, housing, medical care; and also disastrously affect employment - often plunge societies, especially young people, into despair. ${ }^{11}$

As always, fortunately, there are good examples showing sufficient confidence and self-reliance, people who could present the 'other way' (or the way it could work). Ugandan president Yoweri Kaguta Museveni ${ }^{12}$ in 2000 did not accept the reform suggested by the IMF as he wished to leave primary education free from tuition fees. This is of particular importance when we think of the enrolment of girls in societies where they are expected to stay at home to provide the necessary background for the boys to study in hope of a good/better job that would enable them to earn enough money for the entire family. As Stiglitz underlines, Museveni knew that he had to create a culture in which the expectation was that everyone went to school. And he knew he couldn't do that so long as there were any fees charged. So he ignored the advice of the outside experts and simply abolished all school fees. Enrolments soared. As each family saw others sending all of their children to school, it too decided to send its girls to school. ${ }^{13}$

Although the literature is divided on how necessary and effective these structural adjustments were in Africa, there is a fairly general view that in the African context SAPs did not fit; they were essentially not adapted to the African situation. ${ }^{14}$ As Logan was arguing: While this may be the case, and while there were internal factors problematising implementation-educational, political, social deficiencies-international financial institutions claimed this 'domestic inhibition' could be overcome through adjustment. ${ }^{15}$ There is a substantially wide consensus on how essential low budget deficits are for being able to achieve macroeconomic stability. However, it is always crucial to see how to properly balance the increase in taxes and the decrease or reduction of expenditure. In many SAPs, particularly the early ones, the expenditure side of the budget had to bear the main burden. There was little room for raising tax revenues, for example through import duties, without coming into conflict with the trade liberalisation objective. Because of this emphasis on expenditure cuts, public support for infrastructure, education, social services,

10 A. Ismi, 'Impoverishing a Continent: The World Bank and the IMF in Africa', Halifax Initiative 2004, at: http://www.halifaxinitiative.org/updir/ImpoverishingAContinent.pdf, 12 December 2015.

11 Ibid.

12 Museveni was re-elected on 18 February 2016, and continues to exercise top executive power since he seized it in 1986.

13 J.E. Stiglitz, Globalization and Its Discontents, New York 2002, p. 76.

14 Y.A. Yansané, Prospects for Recovery and Sustainable Development in Africa, Westport 1996, p. 255 (Contributions in Afro-American and African Studies, 169).

15 F. Logan, 'Did Structural Adjustment Programmes Assist African Development?', e-IR, 13 January 2015, at <http://www.e-ir.info/2015/01/13/did-structural-adjustment-programmes-assist-african-development/>, 25 January 2016. 
as well as for research and extension, suffered and rural areas, with their high proportion of poor people, were particularly hard hit. ${ }^{16}$ Learning from the failures of the 1980s, throughout the 1990s and ever since adjustments were added a 'human face', and increasingly more attention has been devoted to how governments and other stakeholders can respond to the local needs of the people living in poverty.

\section{THE ALTERNATIVE WAY?}

Stiglitz persuasively argues that economic development in the poorest parts of the world requires sustained aid, good governance, public infrastructure and social goods like education, as well as stock markets, privatisation and free trade. ${ }^{17}$ In this list by now a number of items have gradually been sewn into new webs of interconnectedness. As the SouthSouth co-operation has (re)intensified, new actors have emerged as "caring" partners of African nations.

On the basis of peaceful co-existence and the heritage of Bandung $1955^{18}$, the People's Republic of China appears to have become a 'master of ceremony', and has been playing the game in a clever way, much more efficiently from many angles than other influential actors of the international scene, i.e. either the USA or the European Union. This is proven when, for example, export figures are compared: Africa's exports to China increased at an annual rate of 48 percent between 2000 and 2005, two and half times as fast as the rate of the region's exports to the United States and four times as fast as the rate of its exports to the European Union (EU) over the same period. ${ }^{19} \mathrm{By}$ the year 2010 (and according some others, such as Taylor ${ }^{20}$, already by 2008) the total volume of trade between Africa and China has exceeded the 'dream level' of 100 billion USD. In 2012, total trade almost hit the 200 billion USD figure and stood at 198.5 billion USD - while the U.S. could only keep it at 108.9 billion USD that year. By the year 2015, in a USITC briefing paper from October 2014, it was expected to rise to $\$ 385$ billion by 2015 , according to projections by Standard Chartered Research. ${ }^{21}$

16 F. Heidhues, G. Obare, 'Lessons from Structural Adjustment Programmes and their Effects in Africa', Quarterly Journal of International Agriculture, Vol. 50, No. 1 (2011), p. 59.

17 C. Leadbeater, 'A Series of Mini-accidents Always in Progress', New Statesman, 15 July 2002, p. 52.

18 For more information about the Non-Aligned Movement see: I. Tarrósy, 'Need for Non-Alignment in Our Global World? The Non-Aligned Movement Today and Tomorrow', Croatian International Relations Review, Vol 11, No. 40/41 (2005), pp. 157-163.

19 H.G. Broadman, Africa's Silk Road. China and India's New Economic Frontier, Washington, D.C. 2008, p. 95 (World Bank e-Library).

20 I. Taylor, China and Africa. Engagement and Compromise, London 2006 (Routledge Contemporary China Series, 14).

21 Wen Jin Yuan, 'China's Trade and Investment in Financial Services with Africa', USITC, October 2014, at <https://www.usitc.gov/publications/332/ebot_china_trade_investement_finservices-africa.pdf $>, 23$ November 2015. 
It is understandable that African leaders have favoured China's judgement-free political approach as long as they have been fed up with the West always telling them how they can best reform their countries. ${ }^{22}$ Although the US, for instance, wants to demonstrate that it is still in Africa and remains the big, benevolent, and not necessarily bad sheriff in town, it also tries to warn China, its rival powerbroker ${ }^{23}$ that it is capable of offering challenging sums and deals for Africans to stay engaged with US interests. As a result of ex-president George W. Bush's visit to five African countries in February 2008, more than 5 billion USD were granted to 16 nations to carry out different projects ranging from infrastructural development to good governance. The United Republic of Tanzania alone received 700 million USD for road construction and the improvement of its power supply system, which has been facing a series of severe cuts for months since 2006. In his speech on national security on May 23, 2013, when talking about how foreign aid has been seen as one of the least popular expenditures by basically everybody in the US - even as it does not exceed 1 percent of the total federal budget - President Obama made it explicitly clear that foreign assistance cannot be viewed as charity. It is fundamental to our national security, and it's fundamental to any sensible long-term strategy [and so] has to be part of our strategy. ${ }^{24}$ Any American engagement on the continent, therefore, needs to serve national security, and at the same time, promote global values that America believes in.

Some people, including Mensah, say that China pursues "an aggressive foreign policy engagement on the African continent [...] [due to its] insatiable drive for resources to power its economic engine as it emerges as a new global economic powerhouse". ${ }^{25}$ Global South countries, including African states are in a need of partners, investors offering fair (or easy) co-operation, who do not pressurize while offering financial help (aid), and in this respect China is an ideal "friend" for them. As opposed to the sometimes harsh regulations and former SAPs of the international financial institutions, China has been implementing its policies along the lines of a different philosophy: it does not dictate and does not make aid programmes or loans dependent on whether or not a given country in need of support complies with democratic requirements or liberal market policies. On the basis of peaceful co-existence and the heritage of Bandung, China has been playing, or rather communicating the game in a different way. As Taylor says, China as a seemingly 'refreshing alternative' suits the ruling elites. ${ }^{26}$ Preferring bilateral deals, while it wants to pursue its resource-based foreign policy (not restricted to oil

22 H. De Burgh, Kina - barát vagy ellenség?, Budapest 2007, p. 70.

Focus on Africa Magazine (BBC), Vol. 19, No. 2 (2008), p. 6.

24 B. Obama, 'Text of President Obama's May 23 speech on national security (full transcript)', Washington Post, 23 May 2013, at <https://www.washingtonpost.com/politics/president-obamas-may-23-speech-on-national-security-as-prepared-for-delivery/2013/05/23/02c35e30-c3b8-11 e2-9fe2$-6 e e 52 d 0$ eb7c1_story.html> and cited in I. Tarrósy, "Chimerican” Interests, Africa Policies and Changing US-China Relations', BizPol Affairs, Vol. 1, No. 1 (2013), pp. 11-28.

25 C. Mensah, 'China's Foray into Africa: Ideational Underpinnings and Geoeconomic Interests', African Journal of Political Science and International Relations, Vol. 4, No. 3 (2010), p. 96.

26 I. Taylor, Africa Rising? BRICS - Diversifying Dependency, Rochester, NY 2014 (African Issues). 
at all), neo-colonist charges may sound nonsensical, as along the Confucian doctrine, stressed upon by Chan: Expropriation demands a return - a reciprocation. It means, in practice, substantial front-loading of benefits to an African partner within a naturally vertical and naturally reciprocal relationship. ${ }^{27}$

China has had a long involvement with the continent, with several African countries, going back to the 1960s, after breaking off connections with the Soviet Union. But the current level and intent of China's involvement is different. In those earlier days, Beijing's intentions were primarily motivated by ideological reasons. Their presence was noted by monumental infrastructure projects, with no or relatively small economic development aspect. An exception was the railroad going through Tanzania and Zambia in the eastern part of Africa. The Tanzania-Zambia Railway Authority (TAZARA) project was being financed with an interest-free loan from China that was set to be repaid over a period of 30 years from 1983 onwards. It was built from a joint basis connected to the Tanzanian and Zambian Governments and would be repaid in equal shares. Today, this railway has an enormous significance in infrastructure development in general terms as it provides at the same time both the route and the tool for regional transport. In the 1960s China tried to act separately from the two superpowers of the era and wanted to have independent diplomacy at the time of the Cold War. Later Beijing used the Non-Aligned Movement (NAM) for its own purposes and by pushing the so-called third way it became the undeclared leader of the movement, which helped it in building relationships with the countries of the Global South. At first, these steps were motivated by the declining connections with the Soviet Union, but later on proved to be good decisions and were strengthened in the light of the economic growth and hegemonic ambitions. It is important to reflect on these relations of China with countries of the Global South because the Asian country became a trusted partner for them and Beijing could develop connections into strategic partnerships, deeper than the western states could ever achieve. China cultivated these relations even under the US-dominated unipolar world and by learning from the failure of the western aid-policy it designed a new (or, it is better to say: continued their) way of help: in exchange for aid cargos, credits and infrastructural developments Beijing did not expect structural changes or better human rights situations, just contracts on vital raw materials it needed. Thus, its upgraded aid-policy is not driven by ideological, but principally by economic reasons. As an interview made with former Energy and Mining Minister of Sudan, Mr. Awad Ahmed Al-Jaz shows, the Africans praise their partners for sticking to trade issues and not interfering with internal affairs. The Chinese are very nice, he said. "They don't have anything to do with any politics or problems. Things move smoothly, successfully. They are very hard workers looking for business, not politics. ${ }^{28}$ So, according to the economic motivations, they do not care about human rights issues

S. Chan (ed.), The Morality of China in Africa. The Middle Kingdom and the Dark Continent, London 2013, p. 17.

28 P.S. Goodman, 'China Invests Heavily in Sudan's Oil Industry', Washington Post, 23 December 2004, at <http://www.washingtonpost.com/wp-dyn/articles/A21143-2004Dec22.html>, 12 December 2015. 
and anti-democratic regimes, they make business with everybody, as in the case of $\mathrm{Su}$ dan. This way of help can be upsetting for a number of actors, but we should not forget about the failures of western aid policy, and how that caused serious structural problems. Although there are numerous negative feelings across Africa against the increasing Chinese presence, Chinese actors are not seen any more rapacious or more damaging than the traditional exploiters of Africa's wealth i.e. Western capitalism. ${ }^{29}$

\section{INCREASED CHINESE SUPPORT IN THE AFRICAN EDUCATION SECTOR}

China handles the education sector with attention and care basically for two, very decisive reasons: first, to raise a group of people who can co-operate with China in the future and second, to connect to a "network" caused by the brain-drain invented by western countries, fully exploiting Third World actors. The Action Plans of the Forum on China-Africa Cooperation (FOCAC) ${ }^{30}$ so far has determined several areas of co-operation in the education sector. The Beijing Action Plan (2007-2009) contained the following details with regard to education: The Chinese government decided to help African countries set up 100 rural schools in the next three years; to increase the number of Chinese state scholarships to African students from the current 2,000 per year to 4,000 per year by 2009; to provide annual training for a number of educational officials as well as heads and leading teachers of universities, primary, secondary and vocational schools in Africa; to establish Confucius Institutes in African countries to meet their needs in the teaching of the Chinese language and encourage the teaching of African languages in relevant Chinese universities and colleges. ${ }^{31}$

Later on in 2009 in Sharm el-Sheikh in the fourth Action Plan (2010-2012) the two sides expressed satisfaction with the continued progress in the China-Africa education co-operation in those years. As part of the new document the Chinese Government offered to help African countries to build 50 China-Africa friendship schools in the next three years; to propose the implementation of the 20+20 Cooperation Plan for Chinese and African Institutions of Higher Education to establish a new type of one-to-one inter-institutional co-operation model between 20 Chinese universities (or vocational colleges) and 20 African universities (or vocational colleges); to admit 200 middle and high level African administrative personnel to MPA programmes in China in the next three years; to continue to raise the number of Chinese governmental scholarships and increase the number of scholarships offered to Africa to 5,500 by 2012; to intensify efforts to train teachers for primary, secondary and vocational schools in Af-

29 I. Taylor, Africa Rising?..., p. 121.

30 FOCAC is an official forum between the People's Republic of China and the states in Africa. Its role is to help Beijing contact and stay in touch with all the African states on the highest level and to promote its Africa-policy.

31 FOCAC, Beijing Action Plan (2007-2009), 5.4 section, 16 November 2006, at <http://www.focac. org/eng/ltda/dscbzjhy/DOC32009/t280369.htm>, 12 January 2016. 
rica, and help African countries train 1,500 school headmasters and teachers over the next three years; to continue to promote the development of Confucius Institutes, increase the number of scholarships offered to Chinese language teachers to help them study in China, and double the efforts to raise the capacity of local African teachers to teach the Chinese language. ${ }^{32}$

When we look through these points, the intentions of Beijing are crystal-clear, yet their help is really a substantial step forward. To foster the training of teachers has been a number one need for several African states to handle the teacher-shortage in the newly-built schools. The bilateral collaboration between universities and secondary schools has given the local students the unique opportunity to study abroad.

Beijing continued to devote attention to human resource development at the 2012 Fifth Ministerial Conference of FOCAC. The Beijing Action Plan (20122015) reaffirmed the Chinese commitment to provide government scholarships to Africans, particularly to young people and women. The implementation of the "African Talents Programme" between 2012 and 2015 promised to offer training to 30,000 African professionals in various sectors, together with 18,000 state scholarships to enter the Chinese education system. In terms of scientific collaboration, emphasised is placed on joint research and technology projects, the invitation of Africans to China for postdoctoral research, to offer research instruments and equipment to African researchers who return to their home countries to continue working on their long-term joint research project with their fellow Chinese researchers. With all these China intends to help African countries raise their capacity in research and development innovation. ${ }^{33}$

The most recent documents of FOCAC, including the Johannesburg Action Plan (2016-2018) place education - as part of social development cooperation - higher on the agenda. The target numbers for the coming years include 2,000 full degree placements at Chinese universities and 30,000 government scholarships, together with the training of 200,000 local African vocational and technical personnel and other giving 40,000 training opportunities for Africans in China. With these China aims at helping the young people and women improve their employment skills to enhance the self-development ability of Africa. ${ }^{34}$

Government scholarships have been given to Africans since the 1950s. Since the time when the first students from Egypt received such scholarships in 1956, today the number has been well over 6,000. Although the emphasis - or rather government communication - is focused on these opportunities offered by the Chinese government, those young Africans who study at a Chinese university self-supported outnumber the scholarship- or award-holders. According to Kenneth King, China is

32 FOCAC, Sharm el Sheikh Action Plan (2010-2012), 5.3 section, 12 November 2009, at <http:// www.focac.org/eng/dsjbzjhy/hywj/t626387.htm>, 12 January 2016.

33 FOCAC, Beijing Action Plan (2013-2015), 5.2 and 5.3 sections, 23 July 2012, at <http://www.focac. org/eng/ltda/dwjbzjjhys/t954620.htm>, 12 January 2016.

34 FOCAC, Johannesburg Action Plan (2016-2018), 4.3 section, 25 December 2015, at <http://www. focac.org/eng/ltda/dwjbzjjhys_1/hywj/t1327961.htm>, 12 January 2016. 
evidently an attractive destination for international study for Africans, quite apart from its scholarship provision. ${ }^{35}$

Dozens of Africans study at Hangzhou Normal University located in one of the historic regions of Mainland China. In a focus group meeting organized by the authors in early September 2015, a number of medical graduate students from Somaliland revealed their firm views about how well-recognized Chinese degrees are across the African continent. As Abditafah M. Nuh said, China offers a good ground for getting the knowledge, gaining the necessary experience to find more opportunities after graduation. I want to return home and contribute to the development of my country. I am particularly interested in working in the social relieffield, for an international $N G O .^{36}$

It looks good on your CV that you have your degree from China, and if you speak Mandarin, you are more competitive back home. Translators, for example, are needed to belp different actors both in China and African countries make their business deals in a smooth and professional way, said Cameroonian student at Zheijiang Normal University, Danielle Carole Tangmeu Kenmoe, at another focus group meeting. ${ }^{37}$ Danielle is fluent in Mandarin and confirms the importance of studying abroad in order to understand different approaches to life.

Most of the almost 130 African students at the Shanghai Institute of Technology (SIT) study civil engineering or architecture. In their first year they have to master Chinese and pass the Chinese Proficiency Test (HSK), level IV, so that they can converse in Chinese on a wide range of topics and become able to communicate fluently with native Chinese speakers. In another focus group discussion with students from Cameroon, Madagascar, Niger and the Comoros, the importance of family support was mentioned many times. In many cases it is initiated by the family of the students to study in China, and in the background of this 'push' we find existing links with the Asian giant, as some of the parents had studied or worked in China, or maintain some business-oriented ties with Chinese.

As for the daily realities of interactions between young Africans and the local Chinese populations, the issue of skin color is still high on the agenda. Although interaction is possible, in particular if you speak Mandarin, says Abditafah M. Nuh, we have experienced a number of challenges because we are black. Taxis do not stop if we are alone, but rather when we are with a Chinese friend who is waving to the driver. The less well-educated think that our skin is black because we do not take a bath. They touch it so that they can check if they get painted or not. They are ignorant about us, our cultures, and I think education is the key for them, too, to learn more about Africa and the Africans.

The so-called 'people-to-people' interactions are at the heart of Chinese-African linkages, as they are to increase mutual understanding and friendship between our two

35 K. King, 'Why China Wants African Students to Learn Mandarin', The Conversation, 30 April 2014, at <https://theconversation.com/why-china-wants-african-students-to-learn-mandarin-26079>, 8 November 2015.

36 Recorded by I. Tarrósy on 27 August 2015. The field trip was supported by a research grant from the Pallas Athene Geopolitical Foundation of the Central Bank of Hungary (65/2015 IV.16. decision).

37 Recorded by I. Tarrósy on 28 August 2015. 
peoples and particularly between the younger generations, as former President $\mathrm{Hu}$ Jintao underlined in his speech delivered at the opening ceremony of the Beijing summit of African leaders, FOCAC III. ${ }^{38}$

African students studying at a Chinese university will not only learn proper Mandarin, but will also get closer to Chinese hearts and minds. This is a significant opportunity for all the parties involved as they can function as 'bridges' for future engagements, in particular as far as trade, business deals and investments are concerned. China is not unique in focusing on this soft power element, as basically most of the developed countries and emerging economies behave in the same way, utilizing the same tools in their foreign policies. What makes China different from them is the intensity and concentration, as well as coherent policy coordination, which can result in further gains - hopefully for all the parties involved.

All in all, it is not surprising at all that African governments in general terms tend to turn to other actors: to China, or other Asian actors such as India, Japan, and increasingly to Brazil, as one of the most competitive emerging actors, to name the most influential ones. They want alternative ways to develop, not only the former prescribed methods of the IMF and the World Bank, which in fact, upon the results of the SAPs, have also reformed its programmes towards Africa. The Enhanced Structural Adjustment Facility (ESAF) was created to allow the IMF to continue providing finance to poor countries when it became clear that their financing was too expensive for these countries to repay, admitting their faults in the past. However, as the previous programmes towards poor countries of the Bretton Woods institution showed, this one was also not a real success-story. Based on daily experience, these loans were still too expensive for the destination countries, while the repayment periods were way too short. According to a briefing from June 2000, it appeared to the fund that the ESAF will continue to be an inappropriate source of funds for the poorest countries. While it is clear that adjusting countries require more in the way of concessional finance to support their adjustment efforts, the ESAF is not an appropriate mechanism through which to do so. ${ }^{39}$ The ESAF was replaced by the Poverty Reduction and Growth Facility (PRGF) in November 1999 to mark the change in content and process for IMF concessional support.

\section{EXPANSION OF EDUCATION IN NORTH AFRICA}

Although the focus of the present paper is put on Chinese involvement in African development via the education sector with two Sub-Saharan African examples, the process of developments in this sector across Northern Africa cannot be neglected. Expe-

38 The full text is at <http://news.xinhuanet.com/english/2006-11/04/content_5289052.htm>, 28 November 2015.

39 A. Wood, 'The IMF's Enhanced Structural Adjustment Facility: What Role for Development?', Bretton Woods Project, 14 June 2000, at <http://www.brettonwoodsproject.org/art-16044>, 20 November 2015 . 
rience from the region located north of the Sahara can serve as a point of reference for our study.

There are several substantial features of countries in the northern part of the African continent, which make us turn our attention to the education-development nexus and its relation to societal change. When we are discussing education as a way out of poverty, we also need to examine this region, where the development of education was a top priority in the 1960s, leading to a short-term growth and success. But the fact is, and the events of the Arab Spring of 2011 are underpinning this, that it was not a success story at all. A World Bank report notes that even if these countries invested heavily in education, they could realise only modest economic returns. The report noted that labour market outcomes [in most north African countries] are weak, with much of the educated left unemployed or employed in low-productivity jobs. ${ }^{40}$ And an alarming pattern can be seen in these countries related to the educated (secondary education or greater) young people: educated youth unemployment has been steadily increasing. Also, as a structural problem in Northern Africa, acquiring more education increases the probability of unemployment. ${ }^{41}$

The main factors which condition this phenomenon are the following - based on country reports and studies published by the International Monetary Fund and the World Bank:

1) the expansion of higher education, promoted in this case by guaranteed employment in the public sector until [the beginning of the series of revolts];

2) a high proportion of students who major in humanities and literature ${ }^{42}$;

3) a slow rate of industrialization. ${ }^{43}$

In the first months of 2011 a revolutionary wave of protests, riots and demonstrations took place in North Africa (which spread out in the Arab World). Thousands of citizens of these countries marched to the main squares, government buildings, police stations to protest against their regimes - many of them were young, educated and unemployed. These states faced economic problems, and huge unemployment combined with government corruption and the lack of human rights led to these events.

Despite the expansion of the education sector, economic growth was not significant (and was mainly related to the oil-sector). As the World Bank report noted over the period 1960 to 1990, the average level of education for the adult population in the MENA region [Middle East and North Africa] ${ }^{44}$ rose by an average of 5 percent a year, a rate not

40 World Bank, 'The Road Not Traveled. Education Reform in the Middle East and North Africa', MENA Development Report, 2008. at <http://siteresources.worldbank.org/INTMENA/Resources/EDU_Flagship_Full_ENG.pdf>, 20 November 215.

41 Ibid.

42 In African countries it seems to be a dead end to educate people in these disciplines, both for the education system and for the students as well. While graduate students will be unable to find a job, it is also not profitable for the government to assist this tendency. On the other hand, the profitability of these disciplines was also questioned in Europe in recent times.

43 World Bank, 'The Road Not Traveled...'

44 The MENA region includes: Algeria, Bahrain, Egypt, Iraq, Israel, Jordan, Kuwait, Lebanon, Libya, Mauritania, Morocco, Occupied Palestinian Territory, Oman, Qatar, Saudi Arabia, Syrian Arab Re- 
matched by any other region of the world. The following decade, however, with more and more educated labourers entering the workforce, economic growth in the region averaged only 0.5 percent a year on a per-labourer basis, the lowest schooling/growth relationship in the world. ${ }^{45}$ It is also interesting to mention that despite this growth of the sector, the changes in the area of inequality (access to the education system) were insignificant. As for any way out of poverty, the report noted that poverty levels were essentially stagnant, also despite increased access to education by the poor in most MENA countries. Having made enormous progress on poverty reduction in the earlier period of development, the region has made little progress in the last 15-20 years. [...] The region's average poverty rate fluctuated between 20 and 25 percent in the $1990 s^{46}$ and nowadays as well.

\section{FROM (HIGHER) EDUCATION TO ECONOMIC GROWTH}

Between 1990 and 2010, according to World Bank statistics from 2010, the total number of higher education students in Africa tripled, increasing from 2.7 million in 1991 to 9.3 million in 2006. As Irene Friesenhahn notes, sub-Saharan Africa's higher education sector has expanded massively since the 1970s. Student enrolments across all levels grew from roughly 200,000 about 40 years ago to an estimated ten million [in 2014]. But only a minority of the estimated 1,500 public and private universities across Africa offer graduate programmes. ${ }^{47}$

The progress of education throughout sub-Saharan Africa is obvious, the question is whether the development of this sector is driven by ideological reasons, handled by the governments/regimes considering only quantitative aspects, or driven by tangible economic reasons and labour market needs considering qualitative elements as well. We could see that thoughtless development in northern Africa in some cases worsened the situation, and the progress of sub-Saharan regions in this case (i.e. developing the tertiary system) is slower than in any other regions of the world. But why is higher education important and how does it affect economic growth?

Numerous papers, reports and studies have already outlined the connection between education and economic progress (and improvements in the quality of life). As O'Hara mentions, the 1998/99 World Development Report emphasizes four key strategies that for a successful transition to the new knowledge economy: an appropriate economic and institutional regime, a strong human capital base, a dynamic information infrastructure, and an efficient national innovation systems. All four strategies are inextricably linked to a strong higher education system. ${ }^{48}$

public, Tunisia, United Arab Emirates, Yemen. <http://www.ohchr.org/EN/Countries/MenaRegion/Pages/MenaRegionIndex.aspx>, 27 February 2016.

45 Ibid.

46 Ibid.

47 I. Friesenhahn, 'Making Higher Education Work for Africa: Facts and Figures', SciDevNet, 25 June 2014, at <http://www.scidev.net/global/education/feature/higher-education-africa-facts-figures. html>, 10 December 2015.

48 S. O’Hara (ed.), Higher Education in Africa. Equity, Access, Opportunity, New York 2010. 
Higher education has both private and public benefits, while the former is widely accepted and well-known, the latter is less recognized. Among private benefits we can name higher wages, better employment prospects, and the so-called self-catering, the ability to cope with our values, to save or to invest. It has several secondary benefits such as better health, improved life-quality, etc.

The public benefits are also about the private benefits, as the success of the individuals can affect the whole society: higher wages can raise tax revenues, help greater consumption, contribute to adapting new and better technologies, and so on.

Tertiary schooling can also have less direct benefits for economies. By producing well-trained teachers, it can enhance the quality of primary and secondary education systems and give secondary graduates greater opportunities for economic advancement. By training physicians and other health workers, it can improve a society's health, raising productivity at work. And by nurturing governance and leadership skills, it can provide countries with the talented individuals needed to establish a policy environment favourable to growth. Setting up robust and fair legal and political institutions and making them a part of a country's fabric, and developing a culture of job and business creation, for example, call for advanced knowledge and decision-making skills. ${ }^{49}$ These outcomes can help show the way out for weakened or failed states, but of course (country-)specific features can affect the entire process.

Knowledge produced in higher education has become the most important factor for economic development in the 21st century. Saint et al. demonstrate this point by comparing the research and development investments in OECD countries with those in developing countries like China, India and Brazil, as well as the rest of the world. There seems to be a proportionate relationship between research and development investments and economic development. ${ }^{50}$

\section{THE CASE OF TANZANIA}

The eastern African country still struggles with its economic challenges even if the region is one of the most prosperous regions of Africa, and struggles with its tertiary (higher) education system even though the University of Dar es-Salaam (UDSM) is one of the biggest universities on the continent. The foundation of the university in 1961 was a big step in the life of the countries of east Africa to build a successful education system, but the state university became the instrument of governments, often materializing in bad decisions on personal appointments and over-bureaucratization. Economic problems in Tanzania and events in the East African region quickly led to financial difficulties at UDSM; the 1980s were a particularly low point for the university,

49 D. Bloom, D. Canning, K. Chan, Higher Education and Economic Development in Africa, Harvard University 2005, p. 17, at <http://siteresources.worldbank.org/EDUCATION/Resources/278200-1099079877269/547664-1099079956815/HigherEd_Econ_Growth_Africa.pdf>, 12 November 2015.

50 P. Lolwana, 'Making Higher Education a Public and Social Good in Africa' in S. O'Hara (ed.), Higher Education in Africa... 
which was rife with apathy, inattention to students, and administrative problems. Facilities deteriorated, faculty departed, student strikes became a common feature, and the quality of teaching and learning declined. ${ }^{5 I}$ In the 1990s an upswing started, a more liberal higher education system was institutionalised, unfortunately still with few benefits to the economy. This era saw the introduction of private universities and new public universities. Enrolment in higher education swelled, and government, the private sector, and other donors all made increased funding available. Relations between tertiary institutions and the state improved, the exodus of staff decreased significantly, the expansion and rehabilitation of physical facilities, and an increased focus on student and staff welfare all served to reinvigorate Tanzanian universities. ${ }^{52}$

China became a massive partner for Dar es-Salaam also in the education sector. As we could see, through the FOCAC Action Plans Beijing helped African countries to develop this sector, from primary to tertiary level, moreover in the case of Tanzania, co-operation started long before the FOCAC was established. Well over 600 Tanzanian students had studied in China since relations were established between the two countries, with more than 70 new Tanzanian students commencing studies in China in 2008. Many of the Tanzanian graduates from Chinese universities are fluent in Mandarin Chinese and work with Chinese businesses in Tanzania, notably construction companies. These graduates are valuable assets to the Tanzanian economy. Not only can they help bridge the gap in language and culture, but also through their personal intercultural experience they can assist the government in devising proactive strategies to achieve more effective and meaningful Sino-Tanzanian engagement. It can also be noted that Mandarin has been taught at the University of Dar es-Salaam. ${ }^{53}$

In fulfilment of the Beijing Action Plan, the Chinese government offered to build three primary schools comprising classrooms, library, toilets, and special rooms for girls in addition to playgrounds for approximately 300 students. The value of the schools [was] estimated to be around US\$750,000 each. Several architectural plans were presented to the Tanzanian government which then selected the plans they considered appropriate. According to a senior official within the Ministry of Education (MOE) [who was] consulted by the research team, sites were thereafter selected in full consultation with all relevant stakeholders. ${ }^{54}$

There has been a serious shortage of teachers in Tanzania. By 2011, approximately 52,000 additional teachers were needed in the country ${ }^{55}$ and officials looked for Bei-

51 D. Bloom, D. Canning, K. Chan, Higher Education..., pp. 79-80.

52 Ibid.

53 Based upon I. Tarrósy, 'Two Giants on the Same Soil: A Closer Look at Afro-Asian Relations via Comparing Japanese and Chinese Involvement in Tanzania, Portuguese Journal of International Affairs, No. 6 (2012), pp. 58-59.

54 Centre for Chinese Studies, 'Evaluating China's FOCAC commitments to Africa and mapping the way ahead', Report to the Rockefeller Foundation, 2010, at <http://www.ccs.org.za/wp-content/ uploads/2010/03/ENGLISH-Evaluating-Chinas-FOCAC-commitments-to-Africa-2010.pdf>, 14 December 2015.

55 Data from: <http://planipolis.iiep.unesco.org/upload/Tanzania\%20UR/Tanzania_ICT_Policy_ for_BasicEducation_2007.pdf >,p. 10, 27 February 2016. 
jing's help to address this issue as well. Other possible areas of assistance mentioned were the provision of teaching materials and establishing teacher resource centres. As a follow-up step, a framework agreement was established under the Beijing Action Plan for China to deploy volunteers to Tanzania, especially in the area of education. ${ }^{56}$

Despite bad economic data and the problems of higher education, the government of the country began to understand the connection between education and development; while in 1999 it spent only 2.2\% of the GDP on the sector, in 2007-2008 the figure rose to around 6\%. In 2010 it was measured at 6.18\%, according to the World Bank. Public expenditure on education consists of current and capital public expenditure on education includes government spending on educational institutions (both public and private), education administration as well as subsidies for private entities (students/ households and other privates entities). ${ }^{57}$ According to the United Nations Development Programme's Human Development Report, almost this figure was registered in 2012 as well, standing at $6.2 \%$ of the GDP. ${ }^{58}$

\section{THE CASE OF SUDAN}

The higher education system in Sudan suffered enormously under the regime of Al-Bashir, as many other sectors of the biggest African country (until the 2011 July secession). The regime re-designed education in line with their ideology, which has no relevant effect on the economy, as the government controls all the institutions, determines the curriculum while the universities and colleges have no contact with the labour market. Al-Bashir's government was quick to set in motion a process which could enable it to ensure control over the educated elite as well as higher education institutions. University staff associations were disbanded but student unions, which were controlled by NIF supporters, were allowed to function in order to keep a grip on students' activities in the early days of the government. The abolition of liberal university charters and harassment and dismissal of staff members and students were started in earnest. Higher education in Sudan remains in a continuous state of transition dictated by political, economic and social changes. The current policies adopted by the RCC are the most far reaching ones and they are extremely destructive. Changes in higher education are being dictated by political expediency rather than social or economic needs. ${ }^{59}$ The past decades of Sudan led to a state failure: internal wars, civil war and secession raped the country, which had seen a tremendous economic growth over the past few years, thanks to China. But this GDP growth had nothing to do with education or other sectors of

56 Centre for Chinese Studies, 'Evaluating China’s FOCAC commitments to Africa..., p. 117.

57 Data from: <http://www.tradingeconomics.com/tanzania/public-spending-on-education-total-percent-of-gdp-wb-data.html>, 1 February 2016.

58 Data from: <http://hdr.undp.org/en/content/expenditure-education-public-gdp >, 1 February 2016.

59 Z. El-Hassan, 'Instability, Higher Education \& Development in Sudan: The Effect of Al-Bashir's Higher Education Policies', Sudan Alternative Discourses, Vol. 4 (2008), at <http://www.africa.upenn. edu/Newsletters/sad4.html\#education>, 28 October 2015. 
the economy; it is rather based on the oil-sector, owned by Asian countries, mainly China.

China has shown significant interest in investments in the oil sector of Khartoum. According to statistics, with a huge stake in the country's oil industry, Beijing has become the largest investor, while importing most of the resource-rich African nation's oil output. Given large oil fields, $80 \%$ of Khartoum's revenue comes from oil. But if there is a country in Africa, which would seriously need a decent education system, it is Sudan. In Sudan Chinese companies mostly employ Chinese workers, while the unemployment rate is above 20\% (no official data exist), and with South Sudan's secession, most of the oil revenues have been lost, leaving Khartoum in an economic crisis. Although bilateral trade between China and Sudan is outstandingly high, it is nearly impossible to find co-operation with China in the education sector because the government would not let anybody build schools, only the governments has the right to do so. There are scholarships to Sudanese students but in the majority of cases they are financed by Chinese companies (or Chinese organizations) and the aim of that is to instruct people to be able to work for Chinese companies in the country. There was an article about 10 Sudanese students in the China Daily financed by China Harbor Engineering Co. Ltd. They were awarded Master's degrees by Nanjing-based Hohai University at a graduation ceremony in June 2010 and further groups started their studies in autumn $2010 .^{60}$

As of 2009 , Sudan had 33 universities, with more than 100,000 students,${ }^{61}$ but the Sudanese sample is a classic quantity over quality method, with no benefits for the economy or for the country. However, the biggest problem of any analysis or evaluation is the lack of reliable information.

\section{CONCLUSION}

The education system in Africa is facing similar problems that all the other developing nations have faced. Beside this the IMF and World Bank mostly attached strong recommendations on developing only primary education beside aid and structural programmes. Universal Primary Education [promoted by UNESCO] has encouraged African countries, sometimes aided by international donors, to aggressively meet the Millennium Goals of providing primary education for all and, according to Bergman, Africa is passing the test with flying colours. On the other hand, the success of primary education in Africa has revealed the deficiencies or inadequacies of the post-primary education system. ${ }^{62}$ We can agree with Lolwana who emphasises that the African states should learn and notice the relationship between the levels of education system: if one level expands,

60 Wang Danna, 'China-Sudan Education Cooperation Benefits Students', China Daily, 29 June 2010, at <http://www.chinadaily.com.cn/cndy/2010-06/29/content_10031655.htm>, 27 February 2016.

61 Data from: <http://looklex.com/e.o/sudan.education.universities.htm>, <http://www.sudantribune.com/spip.php?article30170>, and <https://en.wikipedia.org/wiki/List_of_universities_in_Sudan>, 27 February 2016.

62 P. Lolwana, 'Making Higher Education...' 
inequality will be expected on the next level, on the other hand, if a country would like to develop a level (for example the tertiary level), all the other levels of the system should be developed. Mauritius could build a strong tertiary system because of developed primary and secondary education systems. Also, no country [for instance, Sudan ] in the 21st century can afford to treat higher education as an elite system designed for the select few. ${ }^{63}$

In the eyes of many, however, China presents a substantial threat. This is because the extremely cheap Chinese products mean competition for African localities, which seek to pierce into international markets. As Broadman suggests, the African sectors that face more internal competition not only attract more FDI from China and India but also eventually become more effective at penetrating Asian and other markets. ${ }^{64}$ This issue is crucial in the long-term development of any African country, and must be first analysed from an African point of view, representing the real needs and practices of the African peoples, helping them determine self-strategies about any actor in the transnational scene.

From Africa's point of view the picture is more colourful, as there are pros and cons, benefits and dangers embedded in the continent's co-operation with the Asian giant. Chinese involvement in Africa's development is undoubtedly good for Africa as it involves debt cancellation, Foreign Direct Investment, infrastructure and private sector development, and as part of the stretching Chinese 'soft power', the development of the education sector, which in a number of cases is key to any further development. As Gaye underlines, China offers also an alternative route to African countries, [...] [which] may further reduce the already damaged legitimacy of institutions like the World Bank and the International Monetary Fund. ${ }^{65}$ Critical voices, including Gaye's, frequently echo the negative aspect of Sino-African relations, that is China gets more in return. It has now grabbed huge national resources while dumping into the continent cheap industrial manufactured products. ${ }^{66}$ It is therefore in the very interest of Africa to make proper decisions. If Africa does not set its house in order first, there is no way it will achieve anything. [...] Development begins at home. ${ }^{67}$ This is the reason why former South-African President Thabo Mbeki's thoughts about a new "self-definition" for Africa must be taken into account. Africa deserves more and Africa wants more, therefore, as President Mbeki underlined in a lecture held at the University of Havana in 2001, the world - including China - should help Africa find its "self-definition", something that is designed "by the Africans themselves".

To be able to achieve this, educated and well-trained Africans - not only in terms of numbers, but rather first as regards quality - are needed, therefore, for the coming

63 Ibid.

64 H.G. Broadman, Africa's Silk Road..., p. 104.

65 D. Brautigam, A. Gaye, 'Is Chinese Investment Good for Africa?', Council on Foreign Relations Online Debate, 20 February 2007, at <http://www.cfr.org/publication/12622/is_chinese_investment_ good_for_africa.html>, 20 October 2015 .

66 Ibid.

67 Ibid. 
years of African development as such the quality-based development approach of the education sectors all across the continent must be put at the highest position in the African agenda.

\section{BIBLIOGRAPHY}

Bloom D., Canning D., Chan K., Higher Education and Economic Development in Africa, Harvard University 2005, at <http://siteresources.worldbank.org/EDUCATION/ Resources/278200-1099079877269/547664-1099079956815/HigherEd_Econ_ Growth_Africa.pdf >.

Brautigam D., Gaye A., 'Is Chinese Investment Good for Africa?', Council on Foreign Relations Online Debate, 20 February 2007, at <http://www.cfr.org/publication/12622/is_chinese_ investment_good_for_africa.html>.

Broadman H.G., Africa's Silk Road. China and India's New Economic Frontier Washington, D.C. 2008 (World Bank e-Library).

Centre for Chinese Studies, 'Evaluating China's FOCAC commitments to Africa and mapping the way ahead', Report to the Rockefeller Foundation, 2010, at <http://www.ccs.org.za/ wp-content/uploads/2010/03/ENGLISH-Evaluating-Chinas-FOCAC-commitments-to-Africa-2010.pdf>.

Chan S. (ed.), The Morality of China in Africa. The Middle Kingdom and the Dark Continent, London 2013.

Cheru F., African Renaissance. Roadmaps to the Challenge of Globalization, London 2002.

De Burgh H., Kina - barát vagy ellenség?, Budapest 2007.

El-Hassan Z., 'Instability, Higher Education \& Development in Sudan: The Effect of Al-Bashir's Higher Education Policies', Sudan Alternative Discourses, Vol. 4 (2008), at <http:// www.africa.upenn.edu/Newsletters/sad4.html\#education>.

FOCAC, Beijing Action Plan (2007-2009), 16 November 2006, at <http://www.focac.org/ eng/ltda/dscbzjhy/DOC32009/t280369.htm>.

FOCAC, Beijing Action Plan (2013-2015), 23 July 2012, at <http://www.focac.org/eng/ltda/ dwjbzjjhys/t954620.htm>.

FOCAC, Johannesburg Action Plan (2016-2018), 25 December 2015, at <http://www.focac. org/eng/ltda/dwjbzjjhys_1/hywj/t1327961.htm>.

FOCAC, Sharm el Sheikh Action Plan (2010-2012), 12 November 2009, at <http://www.focac.org/eng/dsjbzjhy/hywj/t626387.htm>

Focus on Africa Magazine (BBC), Vol. 19, No. 2 (2008).

Friesenhahn I., 'Making Higher Education Work for Africa: Facts and Figures', SciDevNet, 25 June 2014, at <http://www.scidev.net/global/education/feature/higher-education-africa-facts-figures.html>.

Goodman P.S., 'China Invests Heavily in Sudan's Oil Industry', Washington Post, 23 December 2004, at <http://www.washingtonpost.com/wp-dyn/articles/A21143-2004Dec22.html>.

Heidhues F., Obare G., 'Lessons from Structural Adjustment Programmes and their Effects in Africa', Quarterly Journal of International Agriculture, Vol. 50, No. 1 (2011). 
Ismi A., Impoverishing a Continent: The World Bank and the IMF in Africa, Halifax Initiative 2004, at <http://www.halifaxinitiative.org/updir/ImpoverishingAContinent.pdf>.

King K., 'Why China Wants African Students to Learn Mandarin', The Conversation, 30 April 2014, at <https://theconversation.com/why-china-wants-african-students-to-learn-mandarin-26079>.

Leadbeater C., 'A Series of Mini-accidents Always in Progress', New Statesman, 15 July 2002.

Logan F., 'Did Structural Adjustment Programmes Assist African Development?', e-IR, 13 January 2015, at <http://www.e-ir.info/2015/01/13/did-structural-adjustment-programmes-assist-african-development/>.

Mensah C., 'China's Foray into Africa: Ideational Underpinnings and Geoeconomic Interests', African Journal of Political Science and International Relations, Vol. 4, No. 3 (2010).

O'Hara S. (ed.), Higher Education in Africa. Equity, Access, Opportunity, New York 2010.

Obama B., 'Text of President Obama's May 23 speech on national security (full transcript)', Washington Post, 23 May2013, at <https://www.washingtonpost.com/politics/president-obamas-may-23-speech-on-national-security-as-prepared-for-delivery/2013/05/23/02c35e30-c3b8-11e2-9fe2-6ee52d0eb7c1_story.html>.

Putzel J., Regional and Global Drivers of Conflict: Consequences for Fragile States and Regions. Paper presented at the World Bank Headline Seminar on the Regional and Global Dimensions of Conflict and Peace Building, Addis Ababa, October 10 \& 12 October 2009, at <http://www.lse.ac.uk/internationalDevelopment/research/crisisStates/download/others/RGDriversOfChangeOct09JP.pdf >.

Rotberg R.I., State Failure and State Weakness in a Time of Terror, Cambridge, Mass. 2003.

Rotberg R.I., When States Fail. Causes and Consequences, Princeton 2004.

Stiglitz J.E., Globalization and Its Discontents, New York 2002.

'Tanzania Data Profile', SARUA study, 2012, at <http://www.sarua.org/files/Country\%20Reports\%202012/Tanzania\%20data\%20profile\%20Eng.pdf $>$.

Tarrósy I., “'Chimerican” Interests, Africa Policies and Changing US-China Relations', BizPol Affairs, Vol. 1, No. 1 (2013).

Tarrósy I., 'Need for Non-Alignment in Our Global World? The Non-Aligned Movement Today and Tomorrow', Croatian International Relations Review, Vol 11, No. 40/41 (2005).

Tarrósy I., 'Two Giants on the Same Soil: A Closer Look at Afro-Asian Relations via Comparing Japanese and Chinese Involvement in Tanzania', Portuguese Journal of International Affairs, No. 6 (2012).

Taylor I., Africa Rising? BRICS - Diversifying Dependency, Rochester, NY 2014 (African Issues). Taylor I., China and Africa. Engagement and Compromise, London 2006 (Routledge Contemporary China Series, 14).

'Unraveling the Washington Consensus. An interview with Joseph Stiglitz', Multinational Monitor, Vol. 21, No. 4 (2000), at <http://www.multinationalmonitor.org/mm2000/00april/ interview.html>.

Wang Danna, 'China-Sudan Education Cooperation Benefits Students', China Daily, 29 June 2010, at <http://www.chinadaily.com.cn/cndy/2010-06/29/content_10031655.htm>.

Wen Jin Yuan, 'China's Trade and Investment in Financial Services with Africa', USITC, October 2014, at <https://www.usitc.gov/publications/332/ebot_china_trade_investement_ finservices-africa.pdf $>$. 
Wood A., 'The IMF's Enhanced Structural Adjustment Facility: What Role for Development?, Bretton Woods Project, 14 June 2000, at <http://www.brettonwoodsproject.org/ art-16044>.

World Bank, 'The Road Not Traveled. Education Reform in the Middle East and North Africa', MENA Development Report, 2008, at <http://siteresources.worldbank.org/INTMENA/ Resources/EDU_Flagship_Full_ENG.pdf>.

Yansané Y.A., Prospects for Recovery and Sustainable Development in Africa, Westport 1996 (Contributions in Afro-American and African Studies, 169).

Prof. István TARRÓSY, Ph.D. - Associate Professor of Political Science and Director of the Africa Research Centre, Department of Political Science and International Studies, University of Pécs. Director of the Centre for International Relations. Fulbright Visiting Scholar and Hungarian Eötvös Postdoctoral Fellow at the University of Florida in 2013 and early 2014. Japan Foundation Fellow at Ryukoku University, Kyoto, Japan in 2010. Associate editor of the Hungarian journal of African Studies [Afrika Tanulmányok]. He has conducted fieldwork in several countries in Sub-Saharan Africa.

Zoltán VÖRÖS, Ph.D. - Assistant Lecturer at the Department of Political Science and International Studies, University of Pécs. He works at the independent think-tank IDResearch, and is member of the editorial board of the Hungarian journal of African Studies. Hungarian National Excellence Programme Grantee in 2013. 